\title{
Biochar for Climate Change Adaptation: Effect on Heavy Metal Composition of Telfairia occidentalis Leaves
}

\author{
Doris Akachukwu, Michael Adedapo Gbadegesin, \\ Philippa Chinyere Ojimelukwe, and Christopher John Atkinson
}

\section{Contents}

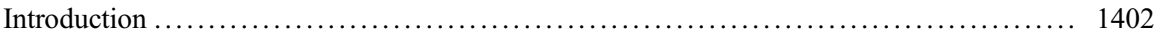

Materials and Methods .................................................... 1409

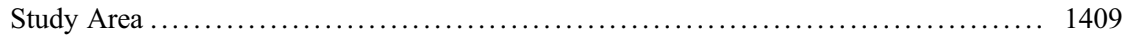

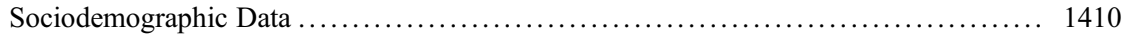

Biochar Preparation ................................................. 1410

Soil Preparation and Biochar Application ................................. 1410

Procurement, Cultivation, and Growth Indices of Telfairia occidentalis .............. 1410

Heavy Metal Determination ............................................ 1410

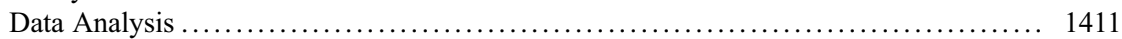

Results and Discussion ............................................. 1411

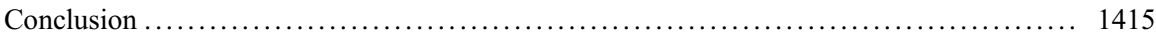

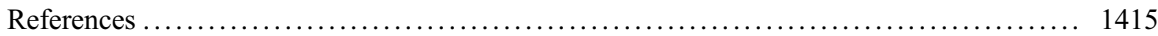

This chapter was previously published non-open access with exclusive rights reserved by the Publisher. It has been changed retrospectively to open access under a CC BY 4.0 license and the copyright holder is "The Author(s)". For further details, please see the license information at the end of the chapter.

D. Akachukwu (ه)

Department of Agriculture, Health and Environment, Natural Resources Institute, University of Greenwich, Chatham, UK

M. A. Gbadegesin

Department of Biochemistry, Faculty of Basic Medical Sciences, University of Ibadan, Ibadan, Oyo State, Nigeria

P. C. Ojimelukwe

Department of Food Science and Technology, Michael Okpara University of Agriculture,

Umudike, Abia State, Nigeria

C. J. Atkinson

Natural Resources Institute, University of Greenwich, London, UK

Department of Agriculture, Health and Environment, Natural Resources Institute, University of Greenwich, Chatham, UK 


\section{Abstract}

Gas flaring is a key contributor of greenhouse gases that causes global warming and climate change. Adaptation measures for tackling impacts of climate change have gained much research interest. This chapter assessed vegetable farmers' perception of gas flaring and the effect of biochar remediation on the heavy metal composition of cultivated Telfairia occidentalis. A gas-flared area, Ohaji/ Egbema L.G.A of Imo State, and a non-gas-flared area, Umudike, Ikwuano L.G.A, were selected for this research. Structured questionnaire was used to elicit information from 120 respondents. Soils were collected from the study sites and transported to the greenhouse. Five different rates, $0 \mathrm{t} \mathrm{ha}^{-1}, 7.1 \mathrm{t} \mathrm{ha}^{-1}$, $13.9 \mathrm{tha}^{-1}, 20.9 \mathrm{t} \mathrm{ha}^{-1}$, and $28.0 \mathrm{t} \mathrm{ha}^{-1}$, of palm bunch biochar were applied to the soils in plastic buckets. After 2 weeks of mineralization, two viable seeds of Telfairia occidentalis were planted in each bucket and watered every other day for 8 weeks. The result revealed that $63 \%$ of vegetable farmers where female, while $37 \%$ were male in the gas-flared area. A total of $97 \%$ of the farmers had knowledge of gas flaring. A total decrease of 55\% percent income, $90 \%$ yield, and $67 \%$ market quality of vegetable farmers was attributed to gas-flared activities. The plant height of cultivated vegetables increased every 2 weeks with greater increase in the test plant. Heavy metal concentration $(\mathrm{Pb}$, and $\mathrm{Cr})$ decreased with increasing biochar rate and was significantly lower for $28.0 \mathrm{t} \mathrm{ha}^{-1}$. Biochar can enhance soil fertility and help immobilize heavy metals. The effect of biochar application on the heavy metal composition is dependent on the rate of application. Biochar use could be a cheap adaptation measure in the face of a changing climate.

\section{Keywords}

Biochar $\cdot$ Climate change adaptation $\cdot$ Gas flaring $\cdot$ Heavy metal $\cdot$ Telfairia occidentalis

\section{Introduction}

Natural gas is a component of petroleum that is released during crude oil exploitation (Mohammed et al. 2016). This natural gas is usually vented or flared (burnt off) (Mohammed et al. 2016). Venting has to do with a direct release of natural gas into the atmosphere without burning, while gas flaring is the indiscriminate burning of natural gas during crude oil exploitation. This practice is common in most countries of the world especially in developing countries like Nigeria where oil companies fail to acquire the needed infrastructure for trapping, storage, and use of natural gas. Gas venting and flaring are responsible for enormous waste of nonrenewable resource, pollution, and an annual release of greenhouse gases which contributes immensely to global warming and climate change (Ajugwo 2013). In 2017, World Bank Global Gas Flaring Reduction Partnership reported that more than 140 billion cubic meters (bcm) of natural gas was flared. This huge volume of gas can serve as a reliable source of energy for the African continent yearly, but on the contrary, it has remained an 
unprecedented source of pollution (Emam 2016; Ismail and Umukoro 2012). As commercial deposits of crude oil was discovered in Nigeria, the nation drifted from agriculture to oil exploitation as its national income base. Oil industry became the nation's gold mine as it accounts for over $80 \%$ of her earnings (Ohimain 2013a, b). The oil companies in the Niger Delta region of Nigeria provided more than $80 \%$ of funds used for allocating national budget (Ede and Edokpa 2015). Nigeria is ranked one of the ten countries of the world with abundant natural gas reserve (Orlando 2006). It has been ranked the second highest in terms of gas flaring activities and the highest in Africa having a whooping gas reserve of over $180 \mathrm{tcm}$ (trillion cubic meter) that has earned it the seventh largest gas reserve worldwide (Oyedepo 2014; Shaaban and Petintin 2014). World Bank reported that Nigeria flared over 7 (seven) billion cubic meters (bcm) of gas in 2018. Nigeria produces over 2,000 billion standard cubic feet of gas yearly (Nriagu et al. 2008). This volume fluctuates regularly because of incessant unrest from militants, activities of miscreants, vandalization, leakages, and so on. Oil exploitation companies in Nigeria are unable to channel natural gas into gainful use since they consider it cost intensive to procure the facilities needed for gas capture. Gas flaring is therefore employed as a safe means to evacuate any associated natural gas during petroleum exploitation, despite its serious deleterious far reaching environmental effects. Threat of flaring gases is common in oil rigs, crude oil refineries, and plants. In advanced countries like the USA, only $1 \%$ of the associated natural gas is flared, while in Nigeria more than $60 \%$ natural gas is flared every day. This large volume of flared gas has the potential to generate substantial revenue to the government of Nigeria if properly harnessed for cooking or industrial uses (Agboola et al. 2011). The flared gas could also be used to generate (power) electricity which could end the challenge of inadequate power supply especially now that the nation is experiencing reduced oil revenues as a consequence of global decrease in oil price (Ojide et al. 2012). This will raise more revenue for Nigeria at this time when oil prices are generally low.

Nigeria losses over 1 billion naira revenue through gas flaring (Campbell 2004; Fluenta 2019) that would have contributed immensely to the nation's economy if the gas was properly captured (Buzcu-Guven and Harriss 2012). Between November 2016 and November 2017, Nigeria flared over 300 billion standard cubic feet of gas which was sold at an exchange rate of 360 naira to 1 dollar with a domestic supply rate of 1.50 USD per 1000 standard cubic feet of gas. This suggests that the nation lost a whooping sum of over 160 billion naira which could have improved her economic base (NNPC 2017). Rules and regulations governing gas flaring in Nigeria are not adequately adhered to by oil-producing companies because such laws are weakly enforced and the penalty levied on defaulters is insignificant (N10 per standard cubic feet). Oil companies in Nigeria lack modern infrastructure needed for gas capture (Okorie 2018); they perceive that such equipment is expensive, and hence its use may not be economically viable. Ironically, there has been increased preference and demand for cooking gas over other sources of fuel, yet, the colossal waste of gas flaring is still been practiced. Locally and internationally, efforts are therefore needed to ensure that regulations governing gas flaring are strictly adhered for the good of man and the environment (Otitoloju and Dan-Patrick 2010).

The composition of the flared natural gas determines the type of pollutants emitted (Fawole et al. 2016). Gas flaring emits greenhouse gases that warm the 
atmosphere, causing climate change (Ukala 2011); also other precursor gases, volatile organic compounds (VOCs), polyaromatic hydrocarbons (PAH), particulate matter, and black carbon from gas flares often contaminate air, soil, and water (Giwa et al. 2014). More than 200 notable toxins have been reported to emanate from gas flares including hydrogen sulfide, toluene, benzene, sulfur dioxide, nitrogen oxide, xylene, and so on (ICF 2006). Particulate matter and precursor gases are among the most toxic pollutants that affect plants and man (Giwa et al. 2014; Yaduma et al. 2013). It releases over 40 billion kilowatts of heat daily into the atmosphere (Ukala 2011). Other pollutants released during gas flaring are soot, organic carbon, particulate matter (Guttikunda and Calori 2013; Giwa et al. 2014; Zhou et al. 2014), and heavy metals (Kampa and Castanas 2008). One percent of global warming arises from gas flaring which contributes over $300 \mathrm{Mt}$ of $\mathrm{CO}_{2}$ into the atmosphere (IPCC 2014a; Amaechi and Biose 2016). Though the practice of gas flaring has been significantly reduced in some countries, Nigeria is yet to record a significant decline despite numerous government strategies (Ite and Ibok 2013); hence, its devastating effects are still felt (Giwa et al. 2014; Oyedepo 2014). Nigeria has lost so much money as a result of gas flaring since the commencement of oil exploitation (Odumugbo 2010). Nigeria loses well over 2 billion dollars as a result of gas flaring yearly (Campbell 2004). This income would have contributed positively to the nation's economy if the gas was properly captured (Buzcu-Guven and Harriss 2012). Gas flaring is responsible for loss of energy resources in oil companies. It affects art works, paints, and monuments (Abua and Ashua 2015; Amadi 2014; Anomohanran 2012; Donwa et al. 2015; Iyorakpo and Odibikuma 2015; Nkwocha and Pat-Mbano 2010; Olukoya 2015; Ubani and Onyejekwe 2013). It affects the general well-being of the Niger Delta dwellers, both psychologically and otherwise (Nriagu et al. 2008). Noise from flare stalks could also affect man and other living things residing around the area. This could lead to loss of some important species or even outright extinction. Pollutants emitted from gas flares are more concentrated at locations close to the flare site. Those farther away from flare sites have reduced pollutant concentrations (Ojeh 2012). Though gas-flared effects are majorly felt within $450 \mathrm{~m}$ radius of flare stack, factors like stack height, flare velocity, temperature, and wind speed affect its impact (Ojeh 2012). When there are notable variations in wind speed and direction, locations close to flare stack may have less concentration of pollutants, while farther locations may have more. Gases can be flared from either a high or low pressure valve, and this affects the concentration of gas emitted and also the noise generated. Global Emission Inventory stated that flaring releases three times more soot than gasoline-driven vehicles (Weyant et al. 2016). It is responsible for the disorientation of water bodies like seas and oceans, for example, for over 40 years now, the ice level of the artic sea has significantly diminished (IPCC 2013). This rise in sea level is a consequence of global warming (Bernstein et al. 2007).

The Niger Delta area of Nigeria occupies more than 7\% of the nation's total land mass with not less than 20 million inhabitants (Tawari and Abowei 2012). The nation has onshore and offshore natural gas reserves located in nine states, namely, Abia, Akwa Ibom, Bayelsa, Cross River, Delta, Edo, Ondo, Imo, and Rivers. They 
comprise a total of 185 local government areas, housing over 800 oil-producing wells and gas operation facilities (Osuji and Onojake 2004). Niger Delta environment is constantly being polluted by activities such as gas flaring, crude oil pollution, pipeline and tanker leakages, and so on (Tawari and Abowei 2012). All these pollutants have over the period altered the ecosystem balance, crop development, and human health. They have also been found to affect microbial activities in the area (Sonibare et al. 2010). A greater percentage of rural dwellers in the Niger Delta engages in different agricultural activities especially fishing and farming as means of livelihood. Unfortunately, gas flaring has negatively affected their survival since it has negatively impacted soil, water, and the environment at large. Gas-flared areas have an elevated ambient temperature as a result of the huge amount of heat (above 45 billion kilowatts) that is released daily from gas-flared points (Aaron 2006). Crops cultivated $2 \mathrm{~km}$ away from gas-flared points are usually scorched by the heat emitted from the gas flares (Anomohanran 2012). Particulates from gas flares can spread as far as $2.61 \times 10^{6} \mathrm{~km}$ away from flare points (Ede et al. 2011). A study conducted by Gobo et al. (2009) revealed that these pollutants could trigger onset of eye, skin, and respiratory diseases. Prolonged exposure to gas flares has been reported to negatively affect blood hematological parameters (Adienbo and Nwafor 2010). Ovuakporaye et al. (2012) also reported presence of skin and respiratory diseases in residents of gas-flared areas as a result of long-term inhalation of gasflared fumes. Gaseous pollutants from gas flares such as nitrogen and sulfur oxides are responsible for acid rain. Acid rain corrodes roofing sheets and walls of buildings. Smog that results from the reaction of nitrogen oxides and hydrocarbons in the presence of UV radiation creates poor visibility (Ana et al. 2009). Other diseases reported to be prevalent in gas-flare areas include respiratory disease, eye and skin disorders, skin cancers (Ana et al. 2009), lung cancer (Ana 2011), and so on. Between 2015 and 1965, a period of 51 years, it was reported that an approximate gas quantity of over $900 \mathrm{bcm}$ and $17 \mathrm{bcm}$ every year with carbon monoxide being the most abundant gas was emitted (Giwa et al. 2019). Elevated levels of deleterious heavy metals have been observed in the air of the Niger Delta area. For instance, Olobaniyi and Efe (2007) reported $0.56 \mathrm{mg} / \mathrm{l}$ of lead in the area. Gas flaring has been reported to reduce yield of crops (Dung et al. 2008; Odjugo 2007; Odjugo and Osemwenkhae 2009; Olisemauche and Avwerosuoghene 2015), induce soil pollution evidenced by increased PAH deposits in soils (Sojinu et al. 2010), and be responsible for various health defects (Bhatia and Wernham 2009; Ekpoh and Obia 2010). The people of the Niger Delta perceive that gas flaring affects their health status and disturbs ecosystem balance generally (Edino et al. 2009).

Living things rely majorly on plants for their survival. The much needed energy and nutrients required by human body for its biochemical processes can be majorly derived from plants. Herbivorous animals (goat, sheep, grass cutters) and omnivorous animals (rat, squirrel, mice) depend on plants for their survival. Plants also provide shelter in the form of vegetation cover for animals that live on land. Cassava and oil palm are among common plants that are often found near gas stacks. The growth (Ozabor and Obisesan 2015) and yield (Achi 2003) of these crops are often affected by gas flaring. Over $70 \%$ of the Niger Delta dwellers are convinced that gas 
flaring has negatively affected their agricultural activities (Adewale and Mustapha 2015), hence their income source. Data obtained from a study in an oil community, Ebedei in Delta, has shown that gas flaring is affecting production of tuber crops such as yam, potato, and cassava including plantain and okra as well (Ozabor and Obisesan 2015). Acid rain arising from gas-flared pollutants is poisonous to plants. It could even lead to death of plants and hence loss of vegetation cover (Amadi 2014). This could further expose the soil to erosion. Symptoms expressed by plants when attacked by acid rain include shedding of leaves, yellow leaves, loss of photosynthetic ability, and even early death (Efe 2011). Acid rain has a more deleterious effect on plants and vegetation that are closer to gas-flared system. Efe (2011) documented that acid rain has negative impact on growth and development of common staple food crops and even cash crops such as rubber. The soil has not been spared from the impacts of acid rain as it has led to loss of important nutrients needed for plant survival. Other researchers including Jacobson (1984), Neufeld et al. (1985), and Efe (2010) have all documented the effect of acid rain on different plant species; and water quality (Ogunkoy and Efi 2003; Efe and Mogborukor 2008). Plants are important sources of medicine because they possess phytochemicals and other bioactive compounds that are of great pharmaceutical importance (Epidi et al. $2016 \mathrm{a}, \mathrm{b})$. The medicinal potential of a plant is a function of its bioactive composition. In another study, Anacletus et al. (2014) and Ifemeje (2015) reported changes in nutritional and phytochemical content of some common edible vegetables such as fluted pumpkin, $\mathrm{H}_{2} \mathrm{O}$ leaf, scent leaf, and bitter leaf. In a similar study, Ujowundu et al. (2013) reported changes in phytochemical (phytate, tannin, alkaloid, and cyanogenic glycoside), proximate composition (ash, moisture, carbohydrate, and proteins), micronutrients $(\mathrm{Ca}, \mathrm{Na}, \mathrm{Mg}, \mathrm{K}$, and $\mathrm{P})$, and vitamins (A, C, and $\mathrm{E}$ ) in African breadfruit and Bambara groundnuts cultivated near flare sites. Phytochemical (flavonoid, tannin, alkaloid, saponin) and trace metals ( $\mathrm{Pb}, \mathrm{Fe}, \mathrm{Cd}, \mathrm{Zn}$ ) of fluted pumpkin could be altered by gas flaring. Okeke and Okpala (2014) reported decreased soil nutrient in two gas-flared communities (Eket and Izombe) of the Niger Delta area.

Since the era of industrial revolution, man has been faced with the challenge of handling the problems arising from excessive crude oil exploitation, gas flaring, and climate change. Methane and carbon dioxide are the most notable greenhouse gases that are responsible for global warming and climate change. Methane has been found to be the most toxic greenhouse gas because it has the ability to induce global warming (86 times) more than $\mathrm{CO}_{2}$ (IPCC 2013). To reverse global warming temperature to below $2{ }^{\circ} \mathrm{C}$ obtained during the pre-industrialization era by the year 2050 , there is need to consciously reduce the volume of crude oil exploited. A certain percentage of fossil fuel, for example, about 50\% natural gas with $30 \%$ crude and $80 \%$ coal, needs to be consciously left unexploited in the earth's crust to avoid undue changes in the earth's environment (McGlade and Ekins 2015; UNFCCC 2015; Zhao and Alexandroff 2019). At the 48th Intergovernmental Panel on Climate Changes conference, following close evaluation of climate change data, scientists came up with a global warming temperature target of $1.5^{\circ} \mathrm{C}$ by the 2035 (IPCC 2018). It is therefore imperative to seek urgent ways of reducing greenhouse gas 
emission as well as seeking other sources of energy for man (Rhodes 2019). The World Bank Global Gas Flaring Reduction Initiative (GGFR 2015) has launched several international and national programs including "Zero Routine Flaring by 2030" Initiative to reduce gas flaring rates. Other bodies that launched campaigns for reduction in gas flaring include the 1992 United Nation Convention on climate change and 1997 Kyoto protocol (Malumfashi 2007). Despite all these strategies, significant changes are yet to be recorded (Elvidge et al. 2009; Fawole et al. 2016), and climatic risk is becoming more pronounced.

Climate change has gained important recognition because of its increased risks and widespread effects. It has become an issue of concern, discussion, and debate in various news media of the world. Its effect on the agricultural sector seems to be at its peak. Farmers are more aware of its existence and risks. It has affected their livelihood and general well-being, thus making adaptation measures very imperative. Climate change is a global environmental threat that consciously or unconsciously affects living and non-living things (Patz et al. 2007). Climate change is an alteration in the state of the climate over a period of 10-30 years or more, depending on man-made activities. The United Nations Framework Convention on Climate Change (UNFCCC) stated that climate change is greatly dependent on human activities that alter the atmospheric equilibrium as well as natural climate change overtime (FAO 2008). Climate change is a global phenomenon that has affected man and his environment (IPCC 2014a, b). Climatic changes manifest in the form of weather variations in temperature and precipitation. Adaptation and mitigation strategies are needed in tackling climate change impacts. Climate adaptation has to do with the capacity to manage variations in climate to minimize possible risks, explore new opportunities, or even both. Most African countries like Nigeria are more susceptible to climate change challenges because they are less aware, suffer more exposure, and have reduced potential for adaptation. Changes in climate are greatly affecting agriculture because it is a substantial source of revenue for the nation. Low level of education, poverty, insufficient infrastructure, and poor planning has contributed to increased exposure to risks in climate. It is therefore said to be involuntary in action and not limited to any particular geographical location. It can increase the virulence of disease-causing organisms (pathogens and pests) and also introduce new alien diseases arising from man-made activities or nature. Climate change could be a short or prolonged change in weather parameters that are already being experienced or forecasted as induced by anthropogenic emissions of noxious gases such as carbon dioxide (Parry et al. 2007). Climate change effects are already being felt globally and even in Africa (Creech et al. 2014). There are variations in climate change impacts from one location to another; for example, in some African countries, there have been cases of increased rainfall pattern and drought (Creech et al. 2014). These variations affect weather forecasting as there are hardly records of regularity in pattern of climatic parameters (Keller 2009). Variations in climatic factors such as increase in temperature and $\mathrm{CO}_{2}$ affect plant's nutritional quality and its phytochemical composition and invariably the animals that consume such plants. It could also lead to increase incidence and severity of epidemics (EU 2015). 
Farmers, their households, and stakeholders in agriculture are at greater risk of climatic change since their activities are rain dependent (Pearce et al. 1996). Agriculture is a major source of employment for Niger Delta dwellers. Adaptation to climatic vulnerability is now a major challenge to farmers, researchers, and policy makers. Most adaptation strategies are geared toward eradication of poverty among households (Mertz et al. 2009). Most farmers are already using their local and traditional practices in trying to adapt to the changes in climate with its associated risks. Climate change adaptation refers to all the steps put in place over many decades to enable a system cope with perceived or actual challenges imposed by climate change (Fankhauser 2017). There is need to put up remediative measures to help recover the ecosystem from prolonged environmental pollution and eradicate associated diseases. To enable residents of Niger Delta remain in their localities and retain their occupation as farmers, it is necessary to seek good and durable adaptation strategies. Many adaptation practices have been employed in most communities. A strategy that will likely be of immense importance is one that will improve the soil productivity of the gas-flared areas. For adaptation to be effective, the reality of climate change impacts must be appreciated (Deressa et al. 2011). The way and manner farmers view climate change determines their approaches toward handling its associated challenges. Their behavioral changes to climate change will influence adaptation options and its effects (Adger et al. 2009). Therefore, a close assessment of farmer's perception of climate risks and their specific adaptation measures will foster better understanding of their local exposure to climate risks, the farmer's adaptive capacity to cope with climate change, as well as to enhance policy formulation to tackle challenges that climate change pose on farmers. Intergovernmental Panel on Climate Change (IPCC) has postulated that the adverse effects of climate change will impact many lives globally in the years to come. Trends in rainfall are expected to drift from normal to abnormal with some areas having less rainfall while others have excess. Maturation time of crops will also be affected by increased temperatures especially in the tropics in the next 10 years. This will ultimately affect global food security and health of man (IPCC 2014a).

As a way to make agricultural activities sustainable in the Niger Delta in the face of climate risks, scientists have attempted different procedures with specific interest in those with little or no side effects to the ecosystem. Biochar is a good example of such material that has been used for soil enrichment with great potentials for soil remediation. Biochar is a biomolecule that is used to amend soils with a view to improving its biological and physical characteristics. It is made by pyrolysis of biomass at temperature range of $204-482{ }^{\circ} \mathrm{C}$ in the presence of little or no oxygen (Swanson 2013). Biochar is rich in carbon (Lehmann and Joseph 2009). It has the immense advantage of being of biological origin. Biochar improves soil physical and chemical properties, fertility, and nutrient availability (Houben et al. 2013). It reduces bioavailability of heavy metals to plants and organisms by adsorbing them (Al-Wabel et al. 2014). It also stabilizes carbon in the soil, reduces the carbon dioxide in the atmosphere (Fang et al. 2015), and reduces greenhouse gas emission (Galloway et al. 2008). Its advantage over other sources of carbon is that it keeps 
carbon long in the soil (Nguyen et al. 2008). Biochar is more durable and effective compared to other carbon sources; it lasts for up to 10,000 years when applied to soil. Stability of biochar depends on its pyrolysis temperature, source material, and soil type (Lehmann and Joseph 2009). Biochar helps in the breakdown of polyaromatic hydrocarbon and adsorbs heavy metals, making them biologically unavailable (Gorovtsov et al. 2018). When biochar is used as a carbon source in soils, the quantity of greenhouse gases emitted decreases by $12 \%$ yearly (Woolf et al. 2010). It is a good remediation material that reduces water loss and improves nutrients of soil (Woolf et al. 2010). Use of biochar for agricultural purposes has proven to be a good climate change adaptation practice in the face of threating global warming and climate change (Lehmann et al. 2006; Woolf et al. 2010). Biochar use is not only is environmentally friendly but also alkalinizes soil (O'Neill et al. 2009) and improves crop growth and development (Graber et al. 2010). Biochar improves soil fertility and has great potential for restructuring the ecosystem. It also increases nutrient bioavailability (Wang et al. 2012), leading to production of healthier crops as well as growth of important microorganisms (Bailey et al. 2011; Smith et al. 2010). It improves soil physicochemical properties like organic carbon, cation exchange capacity, and $\mathrm{pH}$ (Lehmann 2007). Under normal conditions, carbon dioxide is released from decaying plant matter and serves to balance the carbon cycle. The mechanism of action of biochar is that it forms a strong bond with carbon making it assume a very stable configuration and hence slows the process of decomposition. Biochar use traps carbon in the soil while hindering its migration into the atmosphere in the form of $\mathrm{CO}_{2}$. This is therefore a good adaptation process for farmers in gas flaring areas of the Niger Delta region. This will reduce soil water loss and increase soil carbon concentrations and food security (FAO 2008). Biochar has the ability to adsorb toxins, making it unavailable for plant uptake (Sohi et al. 2009). Akachukwu et al. (2018) reported that biochar application enhanced the mineral content of Telfairia occidentalis that was cultivated on gas-flared polluted soil. This chapter compared and evaluated the farmers' perception of gas flaring and effect of biochar on heavy metal composition of Telfairia occidentalis leaves cultivated on gas-flared polluted soils and nongas-flared soils.

\section{Materials and Methods}

\section{Study Area}

This research was conducted with soils collected from two locations, gas-flared area in Ohaji/Egbema L.G.A of Imo State (longitude N $05^{\circ} 33.5^{\prime}$ and latitude E $06^{\circ} 45.2^{\prime}$ ) and non-gas-flared area of Ikwuano L.G.A in Abia state (Longitude $\mathrm{N} 05^{\circ} 28.5^{\prime}$ and Latitude $\mathrm{E} 007^{\circ} 32.5^{\prime}$ ) at a depth of $0-20 \mathrm{~cm}$ using a sterile auger. The soil was stored in clean jut bags and transported to the greenhouse of the National Root Crops Research Institute, Umudike, Abia State. All the soil samples were collected in April. 


\section{Sociodemographic Data}

Well-structured questionnaires were administered randomly to vegetable farmers in the two study sites to assess their perception of gas flaring and its effects on vegetable cultivation and farmers' livelihood.

\section{Biochar Preparation}

Biochar was prepared from sun-dried palm bunches by pyrolysis at $450{ }^{\circ} \mathrm{C}$ in a drum kiln. After cooling, it was milled to finer particles, sieved with a $3 \mathrm{~mm}^{2} \mathrm{mesh}$, and subsequently stored in a clean dry bag until it was ready for use (Karamesouti and Gasparatos 2008).

\section{Soil Preparation and Biochar Application}

Four kilograms of the soil was weighed into clean plastic container. Biochar was applied to the soils at a rate of $0 \mathrm{t} \mathrm{ha}^{-1}, 7.1 \mathrm{tha}^{-1}, 13.9 \mathrm{t} \mathrm{ha}^{-1}, 20.9 \mathrm{t} \mathrm{ha}^{-1}$, and $28.0 \mathrm{t} \mathrm{ha}^{-1}$ in three replicates. The soils and biochar were properly mixed, watered, and allowed to mineralize for 2 weeks.

\section{Procurement, Cultivation, and Growth Indices of Telfairia occidentalis}

Mature and viable seeds of $T$. occidentalis were obtained from a local market at Ndoro, Ikwuano L.G.A, Abia state, Nigeria. Two seeds were cultivated per container and watered once every 2 days. The growth parameters were measured at an interval of 2 weeks. Matured leaves were harvested after 8 weeks of germination, and samples were air-dried and used for heavy metal determination. Growth indices were measured at 2 weeks interval for 8 weeks. Plant height was measured with the aid of a ruler. Stem diameter was measured with the aid of a vernier caliper, while number of leaves was gotten by counting.

\section{Heavy Metal Determination}

A quantity of $0.2 \mathrm{mg}$ of leaf sample was weighed into dry digestion tubes. Five milliliters of nitric acid was added, swirled, and allowed to stand overnight. Tubes were placed into a digestion block with the temperature gradually increasing from room temperature to $120{ }^{\circ} \mathrm{C}$ over about $2 \mathrm{~h}$ with periodical swirling of each tube. Thereafter, the temperature was increased to $180{ }^{\circ} \mathrm{C}$ until about $0.5 \mathrm{~cm}^{3}$ of liquid remained. The digestion tubes were removed from the block and cooled at room temperature. The digest was diluted with ultrapure water, homogenized with a vortex 
mixer, and allowed to stand for a few hours prior to analysis. The heavy metal concentration was determined using an inductively coupled plasma optical emission spectrometer (ICP-OES) (Optima 8000, Perkin Elmer).

\section{Data Analysis}

The data obtained was analyzed using the Statistical Package for Social Sciences (SPSS) version 21.0 for Windows. Mean comparison was done using one way analysis of variance (ANOVA). Duncan multiple test was used to separate means. Significant values were set at $p \leq 0.05$. Data is presented as mean \pm standard deviation (SD).

\section{Results and Discussion}

Figure 1 shows the result of effect of gas flaring on vegetable cultivation and farmers' livelihood. In all the study sites, more than $60 \%$ of vegetable farmers were female while approximately $40 \%$ were male. In the gas-flared area (test), almost all the farmers (97\%) had knowledge of gas flaring while $62 \%$ only knew about gas flaring in the control. This could be because of the absence of gas flaring in

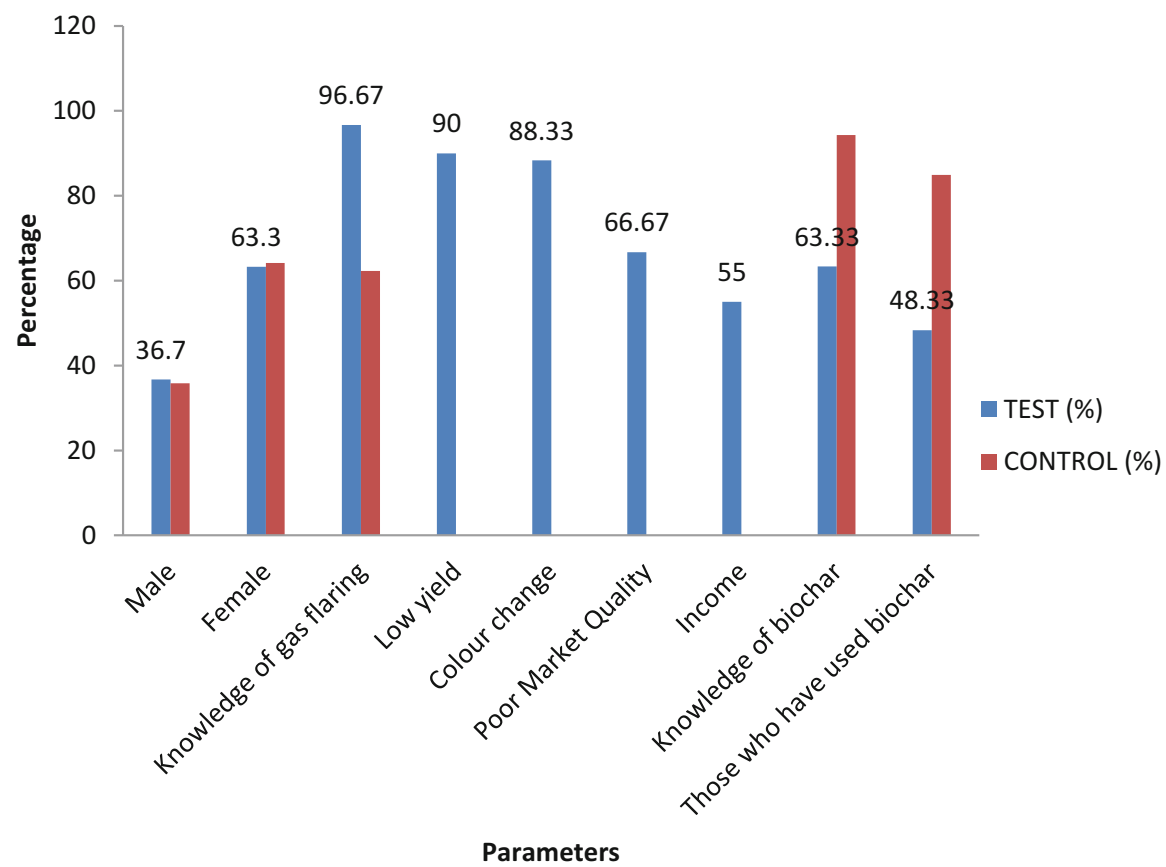

Fig. 1 Effect of gas flaring on vegetable cultivation and farmers' livelihood 
the control area. Also, farmers in the test area had knowledge of biochar (94\%) and had also used it (85\%) unlike the control area where fewer farmers $(63 \%) \mathrm{knew}$ about biochar and had used it (48\%). More than $50 \%$ of the farmers from the test area had experienced low yield, color change, poor market quality, and income reduction as a result of gas flaring activities. This could have impacted negatively on the farmers' standard of living, causing discouragement and lack of interest in farming and invariably affect food security. It could also be a subtle cause of youth restiveness that is prevalent in the Niger Delta area. There were no bar charts for control area possibly because of the absence of gas flaring in the control area.

Table 1 shows the growth indices of T. occidentalis grown on the gas-flared soil and non-gas-flared soil for 8 weeks. Plant height is an important physiological property useful for assessing the growth and cell differentiation in plants (Silva et al. 2019). It is also an expression of how well a plant is able to optimally utilize soil available nutrients. There was general increase in plant height as the weeks progressed from 2 to 8 weeks for vegetables grown on GFTO and NGFTO, respectively. However, the vegetables grown on the gas-flared soils (GFTO, test) showed higher plant height than those grown on the non-gas-flared soil (NGFTO, control). The $0 \mathrm{t} \mathrm{ha}^{-1}$ had no evidence of growth after the first 2 weeks. The $7.1 \mathrm{tha}^{-1}$ group had the highest initial plant height (25.77) for the test vegetable, while the $28.0 \mathrm{tha}^{-1}$ group had the highest (25.87) for the control. The pattern of plant height obtained is similar to that of maize plant treated with Daniella oliviera wood biochar reported by Aminu and Shamsuddeen (2019). Stem diameter of test vegetables was higher than the control in a non-dose-dependent manner and also reduced with increase in number of weeks in both the test and control vegetables; however, their differences were not statistically different. Dispenza et al. (2016) obtained a dosedependent increase in stem diameter for substrates of Euphorbicia treated with $20 \%$, $60 \%$, and $80 \%$ conifer wood biochar. Number of leaves increased with increase in weeks (Okonwu and Mensah 2012).

Table 2 presents the heavy concentration of $T$. occidentalis leaves cultivated on biochar-remediated soils from gas-flared and non-gas-flared area. The Fe and $\mathrm{Zn}$ concentrations of the gas-flared T. occidentalis (GFTO) decreased from $13.9 \mathrm{tha}^{-1}$ to $28.0 \mathrm{t} \mathrm{ha}^{-1}$ biochar while that of the non-gas-flared T. occidentalis (NGFTO) decreased from $0 \mathrm{t}$ ha ${ }^{-1}$ to $20.9 \mathrm{tha}^{-1}$ biochar. There was no significant $(p>0.05)$ difference in Fe concentration between the GFTO and NGFTO except for the $13.9 \mathrm{t} \mathrm{ha}^{-1}$ biochar group that was markedly increased in the GFTO vegetable. No significant difference was observed in $\mathrm{Cu}$ concentration for GFTO and NGFTO for all the groups except for the $7.1 \mathrm{t} \mathrm{ha}^{-1}, 13.9 \mathrm{t} \mathrm{ha}^{-1}$, and $20.9 \mathrm{tha}^{-1}$ biochar groups that were significantly lower for NGFTO compared to the control. Lead $(\mathrm{Pb})$ and $\mathrm{Cr}$ concentrations were significantly $(p<0.05)$ higher for GFTO from $7.1 \mathrm{t} \mathrm{ha} \mathrm{ha}^{-1}$ biochar, while its concentration decreased from $7.1 \mathrm{t} \mathrm{ha}^{-1}$ to $20.9 \mathrm{t} \mathrm{ha}^{-1}$ biochar compared to their control. Cobalt concentration was highest for GFTO treated with $7.1 \mathrm{t} \mathrm{ha}^{-1}$ biochar while that of $28.0 \mathrm{t} \mathrm{ha}^{-1}$ GFTO had the least. In the NGFTO, the cobalt concentration decreased from $7.1 \mathrm{tha}^{-1}$ to $20.9 \mathrm{t} \mathrm{ha}^{-1}$ biochar. Cadmium concentration in both the GFTO and NGFTO decreased with increasing biochar concentration. Nickel concentration was highest in the GFTO-treated with $7.1 \mathrm{tha}^{-1}$ 


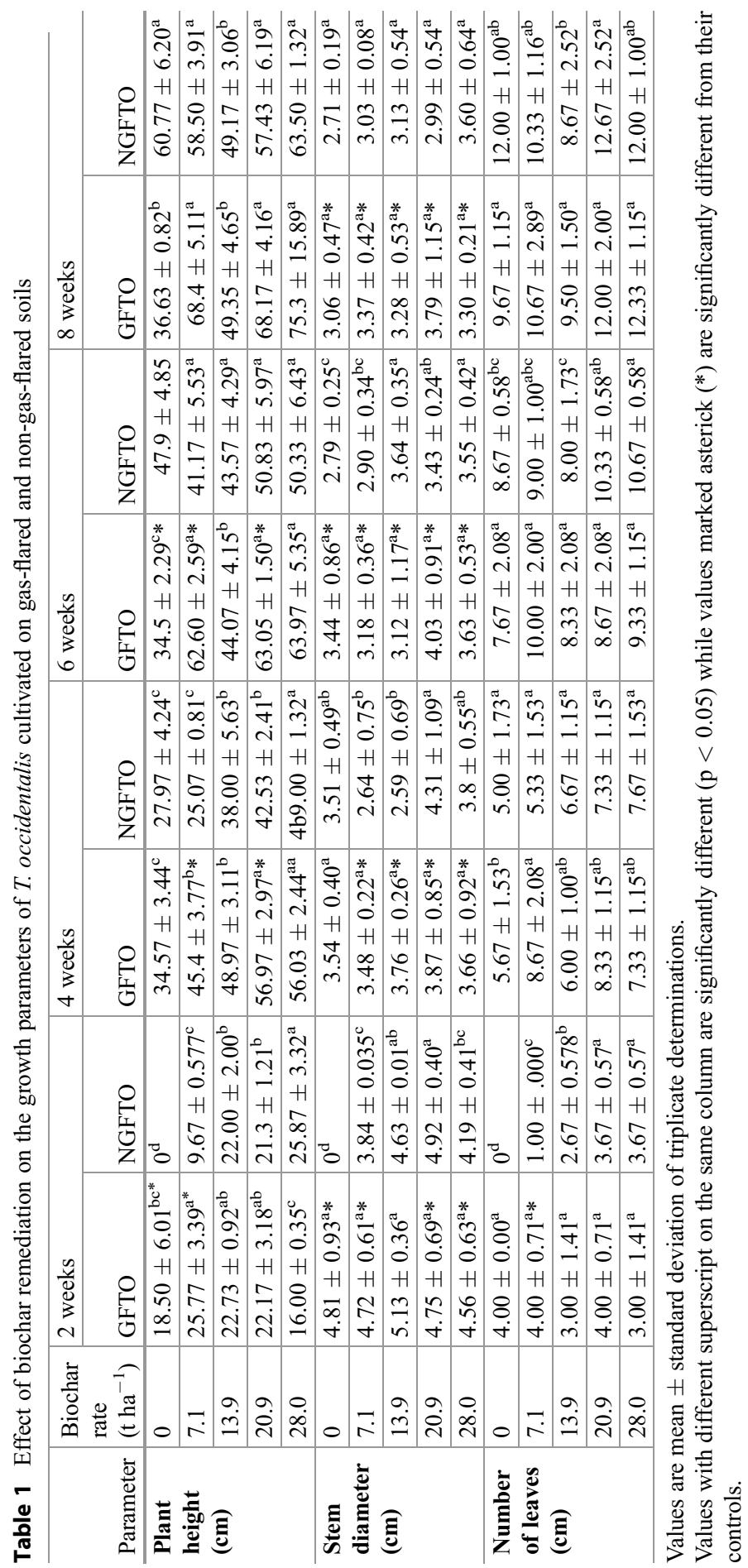




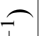

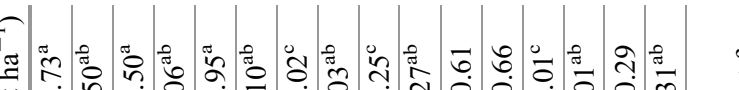

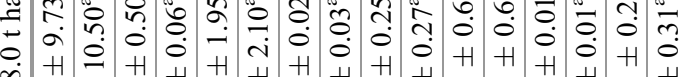

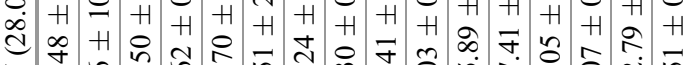

$\frac{n}{7}$

ż人

$\overline{0}$

(1)

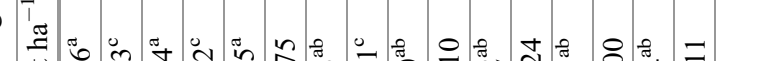

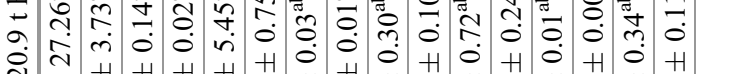

d + H H H H H H H H H H

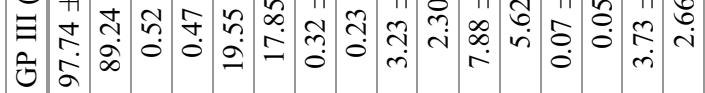

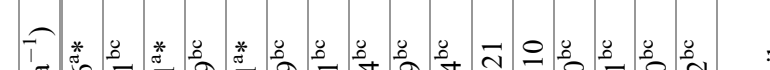

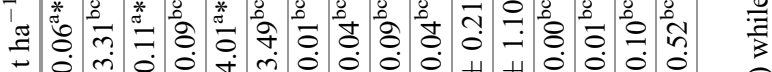

(1) H H H H H H H H

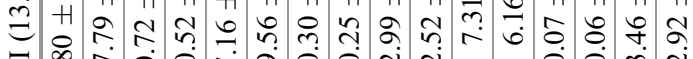

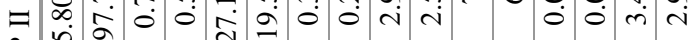

७ิ

$\mathrm{ri}$

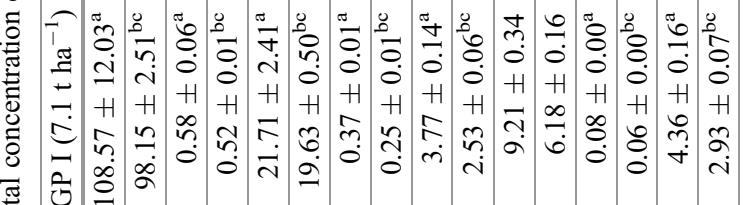

离

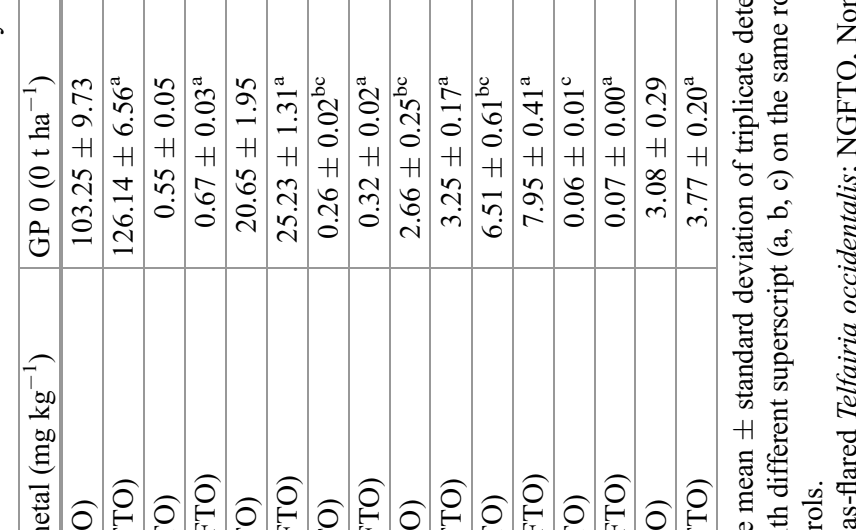

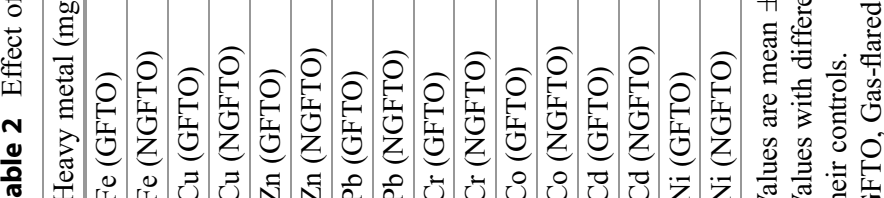

$\&$ \& 80

党 
biochar and lowest for the $28.0 \mathrm{tha}^{-1}$ biochar-treated group, while the NGFTO treated with $20.9 \mathrm{t} \mathrm{ha}^{-1}$ biochar had the least nickel concentration. Biochar administered to the two soils reduced uptake by plants as shown by our result. Human beings are often exposed to heavy metal contamination through the food chain as they are transferred from soil to plants (Khan et al. 2010). They cause serious health challenges when their concentrations exceed the normal threshold (Al-Wabel et al. 2014). Some heavy metals are known to alter normal body metabolism, disrupt transfer of hereditary materials from parents to offsprings, and affect proper growth and development of fetus (Ali et al. 2013). Heavy metals such as chromium, copper, cadmium, and lead are well known for their toxicity when consumed at concentrations beyond the permissible limits (Dursun 2006; Kurniawan et al. 2006). Copper contamination can cause gastrointestinal cancer in humans (Turkdogan et al. 2003). Cadmium toxicity is responsible for kidney damage and can cause "itai-itai" in man. Zinc is an essential element that is toxic at higher concentrations (Baccio et al. 2005). Chromium is harmful to plants and animals; chromium (IV) ion alters soil biological activities and is carcinogenic (Javied et al. 2009). Cobalt causes bone marrow hyperplasia, acute poisoning, allergic reactions, seizures, and paralysis of nervous system. Lead is very poisonous; it affects the cardiovascular system and causes stroke and cognitive impairment (Evangelou et al. 2007). Our finding has shown that heavy metal adsorption by the T. occidentalis leaves decreased as the rate of biochar application increased with $20.9 \mathrm{tha}^{-1}$ being the most effective. This result suggest that using biochar to cultivate this vegetable could lead to production of better quality vegetables, reducing the prevalence of heavy metal toxicity and hence improving nutrition of the consumers.

\section{Conclusion}

The chapter has shown that vegetable farming is mostly engaged by females. Biochar use enhanced the growth parameters and reduced heavy metal uptake by the plants. Therefore, biochar use should be encouraged to remediate heavy metal polluted soils, to ensure maximum crop yield and food security. Increased sensitization is needed to encourage the use of biochar in gas flaring polluted areas to ensure that good quality vegetables are available for consumers.

Acknowledgments This research is supported by funding from the Department for International Development (DFID) under the Climate Impacts Research and Leadership Enhancement (CIRCLE) program.

\section{References}

Aaron KK (2006) Human rights violation and environmental degradation in the Niger-Delta. In: Porter E, Offord B (eds) Activating human rights. Barnes, Oxford/New York

Abua MA, Ashua SW (2015) The impact of gas flaring on plant diversity in Ibeno local government area. J Agric Ecol Res Int 4(1):10-17 
Achi C (2003) Hydrocarbon exploitation, environmental degradation and poverty: the Niger Delta experience. In: Diffuse pollution conference, Dublin 2003 2B policy/socio-economics

Adewale OO, Mustapha U (2015) The impact of gas flaring in Nigeria. Int J Sci Technol Soc 3 (2): $40-50$

Adger WN et al (2009) Are there social limits to adaptation to climate change? Clim Chang 93 (3-4):335-354

Adienbo OM, Nwafor A (2010) Effect of prolong exposure to gas flaring on some haematological parameters of humans in the Niger Delta region of Nigeria. J Appl Sci Environ Manag 14 (1): $13-15$

Agboola MO, Nwulu NI, Egelioglu F, Agboola OP (2011) Gas flaring in Nigeria: opportunity for household cooking utilization. Int J Therm Environ Eng 2:73

Ajugwo AO (2013) Negative effects of gas flaring: the Nigerian experience. J Environ Pollut Hum Health 1:6-8

Akachukwu D, Gbadegesin MA, Ojimelukwe PC, Atkinson CJ (2018) Biochar remediation improves the leaf mineral composition of Telfairia occidentalis grown on gas flared soil. Plants 7(3):57

Ali H, Khan E, Sajad MA (2013) Phytoremediation of heavy metals-concepts and applications. Chemosphere 91(7):869-881

Al-Wabel MI, Usman ARA, El-Naggar AH, Aly AA, Ibrahim HM, Elmaghraby S, Al-Omran A (2014) Conocarpus biochar as a soil amendment for reducing heavy metal availability and uptake by maize plants. Saudi J Biol Sci 22:503-511

Amadi AN (2014) Impact of gas-flaring on the quality of rain water, groundwater and surface water in parts of Eastern Niger Delta, Nigeria. J Geosci Geomatics 2(3):114-119

Amaechi CF, Biose E (2016) Gas flaring: carbon dioxide contribution to global warming. J Appl Sci Environ Manag 20:309-317. https://www.ajol.info/index.php/jasem/article/view/140405. Accessed 19 Dec 2019

Aminu H, Shamsuddeen L (2019) Effect of Daniella olivera wood biochar on the growth and biomass of maize (Zeamays L.) in Lafia, North Central Nigeria. J Dryland Agric 5(3):25-32

Ana GR (2011) Air pollution in the Niger Delta area: scope, challenges and remedies. In: Khallaf M (ed) The impact of air pollution on health, economy, environment and agricultural sources. InTech. ISBN: 978-953-307-528-0. http://www.intechopen.com/books/the-impactofairpollution-on-health-economy-environment-and-agricultural-sources/airpollution-in-theniger-delta-area-scopechallenges-and-remedies

Ana GREE, Sridhar MKC, Bamgboye EA (2009) Environmental risk factors and health outcomes in selected communities of the Niger Delta area, Nigeria. Perspect Public Health 129(4): 183-191

Anacletus F, Adisa OI, Uwakwe A (2014) Effect of gas flaring on some phytochemicals and trace metals of fluted pumpkin (Telferia occidentalis). J Environ Earth Sci 4(16):1-5

Anomohanran O (2012) Thermal effect of gas flaring at ebedei area of Delta State, Nigeria. Pac J Sci Technol 13:555-560. http://www.akamaiuniversity.us/PJST13_2_555.pdf. Accessed 19 Dec 2019

Baccio D, Kopriva S, Sebastiani H, Rennenberg L (2005) Does glutathione metabolism have a role in the defence of poplar against zinc excess. New Phytol 167:73-80

Bailey VL, Fansler SJ, Smith JL, Bolton H (2011) Reconciling apparent variability in effects of biochar amendment on soil enzyme activities by assay optimization. Soil Biol Biochem 43:296

Bernstein L, Bosch P, Canziani O, Chen Z, Christ R, Davidson O (2007) Climate change 2007: synthesis report. Summary for policymakers. IPCC, Geneva, p 22

Bhatia R, Wernham A (2009) Integrating human health into environmental impact assessment: an unrealized opportunity for environmental health and justice. Ciênc Saúde Colet 14(4): $1159-1175$

Buzcu-Guven B, Harriss R (2012) Extent, impacts and remedies of global gas flaring and venting. Carbon Manag 3(1):95-108 
Campbell LGM (2004) A voluntary standard for global gas flaring and venting reduction. World Bank Group, Oil, Gas, Mining and Chemicals Department, Washington, DC

Creech H, Akoh B, Parry JE (2014) ICTs for climate change adaptation in Africa. World Bank, Washington, DC

Deressa TT, Hassan RM, Ringler C (2011) Perception of and adaptation to climate change by farmers in the Nile basin of Ethiopia. J Agric Sci 149:23

Dispenza V, De Pasquale C, Fascella G, Mammano MM, Alonzo G (2016) Use of biochar as peat substitute for growing substrates of Euphorbia $\times$ lomi potted plants. Span J Agric Res 14(4): e0908

Donwa PA, Mgbame CO, Utomwen OA (2015) Gas flaring in the oil and gas sector in Nigeria. Int J Commer Manag Res 1(1):28-39

Dung E, Bombom L, Agusomu T (2008) The effects of gas flaring on crops in the Niger Delta, Nigeria. GeoJournal 73(4):297-305

Dursun AYA (2006) Comparative study on determination of the equilibrium, kinetic and thermodynamic parameters of biosorption of copper(II) and lead(II) ions onto pretreated Aspergillus Niger. Biochem Eng J 28(2):187-195

Ede PN, Edokpa DO (2015) Regional air quality of the Nigeria's Niger Delta. Open J Air Pollut $4: 7-15$

Ede PN, Edokpa DO, Ayodeji O (2011) Aspects of air quality status of Bonny Island, Nigeria attributed to an LNG plant. Energy Environ 22(7):891-909

Edino MO, Nsofor GN, Bombom LS (2009) Perceptions and attitudes towards gas flaring in the Niger Delta, Nigeria. Enviromentalist 30:67-75

Efe SI (2010) Spatial variation in acid and some heavy metal composition of rainwater harvesting in the oil producing region of Nigeria. Nat Hazards 55:307

Efe SI (2011) Spatial variation of acid rain and its ecological effect in Nigeria. In: Proceedings of the environmental management conference, Federal University of Agriculture, Abeokuta, pp 381-396

Efe SI, Mogborukor JOA (2008) Acid rain in the Niger Delta region: implication on water resource crises. In: Proceedings, international conference on the Nigerian state, oil industry and the Niger Delta, 11-13th March, 2008, Glory land Cultural Centre, Yenagoa

Ekpoh I, Obia A (2010) The role of gas flaring in the rapid corrosion of zinc roofs in the Niger Delta region of Nigeria. Environmentalist 30(4):347-352

Elvidge CD, Ziskin D, Baugh KE, Tuttle BT, Ghosh T, Pack DW, Erwin EH, Zhizhin M (2009) A fifteen year record of global natural gas flaring derived from satellite data. Energies 2(3): 595-622

Emam EA (2016) Environmental pollution and measurement of gas flaring. Int J Innov Res Sci Eng Technol 2:252-262. https://pdfs.semanticscholar.org/0463/ 5c29995aefa3f8f7d431d4ca6a35d22c4813.pdf. Accessed 19 Dec 2019

Epidi JO, Izah SC, Ohimain EI, Epidi TT (2016a) Phytochemical, antibacterial and synergistic potency of tissues of Vitex grandifolia. Biotechnol Res 2(2):69-76

Epidi JO, Izah SC, Ohimain EI (2016b) Antibacterial and synergistic efficacy of extracts of Alstonia boonei tissues. Br J Appl Res 1(1):0021-0026

European Union (2015) Life and climate change bulletin. Publications Office of the European Union, Luxembourg, pp 1-113. https://www.google.com/search?client=firefox-b-d\&q=life_ climate_change_adaptation_en

Evangelou MWH, Ebel M, Schaeffer A (2007) Chelate assisted phytoextraction of heavy metals from soil. Effect, mechanism, toxicity, and fate of chelating agents. Chemosphere 68 (6):989-1003

Fang Y, Singh B, Singh BP (2015) Effect of temperature on biochar priming effects and its stability in soils. Soil Biol Biochem 80:136-145

Fankhauser S (2017) Adaptation to climate change. Ann Rev Resour Econ 9(1):209-230

FAO (Food and Agriculture Organization of the United Nations) FAOSTAT (2008) 
Fawole OG, Cai XM, MacKenzie AR (2016) Gas flaring and resultant air pollution: a review focusing on black carbon. Environ Pollut 216:182-197

Fluenta (2019) Reducing flaring in Nigeria: presidential approval. https://www.fluenta.com/ reducing-flaring-in-nigeria-presidential-approval/. Accessed 16 July 2020

Galloway JN, Townsend AR, Erisman JW, Bekunda M, Cai Z, Freney JR, Martinelli LA, Seitzinger SP, Sutton MA (2008) Transformation of the nitrogen cycle: recent trends, questions, and potential solutions. Science 320:889-892

Giwa SO, Adama OO, Akinyemi OO (2014) Baseline black carbon emissions for gas flaring in the Niger Delta region of Nigeria. J Nat Gas Sci Eng 20:373-379

Giwa SO, Kuye SI, Adama KO (2019) Gas flaring attendant impacts of criteria and particulate pollutants: a case of Niger Delta region of Nigeria. J King Saud Univ Eng Sci 31:209-217

Global Gas Flaring Reduction Partnership (GGFR) (2015) https://www.worldbank.org/en/ programs/gasflaringreduction. Accessed 5 Nov 2019

Gobo AE, Richard G, Ubong IU (2009) Health impact of gas flares on Igwurata / Umuchem communities in Rivers State. J Appl Sci Environ Manage 13(3):27-33

Gorovtsov AV, Sazykin IS, Sazykina MA (2018) The influence of heavy metals, polyaromatic hydrocarbons, and polychlorinated biphenyls pollution on the development of antibiotic resistance in soils. Environ Sci Pollut Res 25(10):9283-9292

Graber ER, Harel YM, Kolton M, Cytryn E, Silber A, David DR, Tsechansky L, Borenshtein M, Elad Y (2010) Biochar impact on development and productivity of pepper and tomato grown in fertigated soilless media. Plant Soil 337:481-496

Guttikunda SK, Calori G (2013) A GIS based emissions inventory at $1 \mathrm{~km} \times 1 \mathrm{~km}$ spatial resolution for air pollution analysis in Delhi, India. Atmos Environ 67:101-111

Houben D, Evrard L, Sonnet P (2013) Mobility, bioavailability and PH-dependent leaching of cadmium, zinc and lead in a contaminated soil amended with biochar. Chemosphere 92:1450-1457

ICF (2006) Nigeria: guidebook for carbon credit development for flare reduction projects. International. June 2006

Ifemeje JC (2015) Effect of gas flaring on the anti-nutritional composition of four green leafy vegetables from Eleme in Rivers State, Nigeria. Int J Environ Pollut Solut 3(1):31-37. Columbia International Publishing

IPCC (2013) Climate change 2013. The physical science basis. Contribution of working group I to the fifth assessment report of the Intergovernmental Panel on Climate Change. Cambridge University Press, Cambridge, UK, 2014

IPCC (2014a) Climate change 2014. Impacts, adaptation and vulnerability-contribution of working group II to the fifth assessment report of Intergovernmental Panel on Climate Change. Cambridge University Press, Cambridge, UK

IPCC (2014b) Climate change 2014: synthesis report. Intergovernmental panel on climate change, Geneva

IPCC (2018) Global warming of $1.5^{\circ} \mathrm{C}$. An IPCC Special report on the impacts of global warming of $1.5^{\circ} \mathrm{C}$ above pre-industrial levels and related global greenhouse gas emission pathways, in the context of strengthening the global response to the threat of climate change. Intergovernamental Panel on Climate Change. https://www.ipcc.ch/sr15/download/\#full. Accessed 5 Nov 2019

Ismail OS, Umukoro GE (2012) Global impact of gas flaring. Energy Power Eng 4(4):290-302

Ite AE, Ibok UJ (2013) Gas flaring and venting associated with petroleum exploration and production in the Nigeria's Niger Delta. Am J Environ Prot 1:70-77

Iyorakpo J, Odibikuma PW (2015) Impact of gas flaring on the built environment: the case of Ogba/Egbema/Ndoni Local Govt Area, Rivers State, Nigeria. Eur Sci J 11(26):83-95

Jacobson JS (1984) Effect of acidic aerosol, fog, mist and rain on crops and trees. Philos Trans R Soc Lond B 49:327-338

Javied S, Mehmood T, Choodhry MM, Tufail M, Irfan N (2009) Heavy metal pollution from phosphate rock used for the production of fertilizer in Pakistan. Microchem J 91:94-99 
Kampa M, Castanas E (2008) Human health effects of air pollution. Environ Pollut 151:362-367

Karamesouti M, Gasparatos D (2008) Sustainable management of soil phosphorus in a changing world. In: Rakshit S, Abhilash PC, Singh HB, Ghosh S (eds) Adaptive soil management - from theory to practices. Springer, Berlin

Keller M (2009) Climate risks and development projects: an assessment report for a communitylevel project in Guduru, Oromiya, Ethiopia, Swiss Interchurch Aid (HEKS)

Khan S, Rehman S, Khan AZ, Khan MA, Shah MT (2010) Soil and vegetables enrichment with heavy metals from geological sources in Gilgit, Northern Pakistan. Ecotoxicol Environ Saf 73:1820-1827

Kurniawan TA, Chan GY, Lo WH, Babel S (2006) Comparisons of low-cost adsorbents for treating waste waters laden with heavy metals. Sci Total Environ 366(2-3):409-426

Lehmann J (2007) Bio-energy in the black. Front Ecol Environ 5:381-387

Lehmann J, Joseph S (2009) Biochar for environmental management: an introduction. In: Lehmann J, Joseph S (eds) Biochar for environmental management, science and technology. Earthscan, London, pp 1-12

Lehmann J, Gaunt J, Rondon M (2006) Biochar sequestration in terrestrial ecosystems-a review. Mitig Adapt Strateg Glob Chang 11:395-419

Malumfashi GI (2007) Phase-out of gas flaring in Nigeria by 2008: the prospects of a multi-win project. Review of the regulatory, environmental and socio-economic issues. Niger Gas Flaring Pet Train J 4:1-39

McGlade C, Ekins P (2015) The geographical distribution of fossil fuels unused when limiting global warming to $2{ }^{\circ} \mathrm{C}$. Nature $517: 187-190$

Mertz O, Mbow C, Reenberg A, Diouf A (2009) Farmers' perceptions of climate change and agricultural adaptation strategies in rural Sahel. Environ Manag 43(5):804-816

Mohammed AA, Mohammed MA, Ahmed MM (2016) Recovery of natural gas liquids and produce liquified petroleum gas from associated natural gas. Sudan University of Science \& Technology. Avaialable at: http://repository.sustech.edu/handle/123456789/15090

Neufeld HS, Jernstedt JA, Haines BL (1985) Direct foliar effects of simulated acid rain, I. Damage, growth and gas exchange. New Phytol 99(3):389-405

Nguyen B, Lehmann J, Kinyangi J, Smernik R, Riha SJ, Engelhard MH (2008) Long-term black carbon dynamics in cultivated soil. Biogeochemistry 89:295-308

Nigerian National Petroleum Corporation (2017) NNPC: Nigeria drops to seventh highest gas flaring country. https://www.thisdaylive.com/index.php/2017/04/03/nnpc-nigeria-dropstoseventh-highest-gas-flaring-country/. Accessed 20 July 2020

Nkwocha EE, Pat-Mbano EC (2010) Effect of gas flaring on buildings in the oil producing rural communities of River State, Nigeria. Afr Res Rev 4(2):90-102

Nriagu J, Udofia EA, Ekong I, Ebuk O, Sambo AS (2008) The role of energy in achieving millennium development goal (MDGs). Keynote address at the national engineering technology conference (NETec 2008). Ahmadu Bello University, Zaria held on 1st of April, 2008

O’Neill B, Grossman J, Tsai MT, Gomes JE, Lehmann J, Peterson J, Neves E, Thies JE (2009) Bacterial community composition in Brazilian Anthrosols and adjacent soils characterized using culturing and molecular identification. Microb Ecol 58:23-35

Odjugo PAO (2007) Some effects of gas flaring on the microclimate of yam and cassava production in Erhorike and environs. Delta State, Nigeria. Niger Geogr J 5:43

Odjugo PAO, Osemwenkhae EJ (2009) Natural gas flaring affects microclimate and reduces maize (Zea mays) yield. Int J Agric Biol 11:408-412

Odumugbo CA (2010) Natural gas utilisation in Nigeria: challenges and opportunities. J Nat Gas Sci Eng 2:310-316

Ogunkoy OO, Efi EJ (2003) Rainfall quality and sources of rainwater acidity in Warri area of the Niger Delta, Nigeria. J Min Geol 39(2):125-130

Ohimain EI (2013a) Can the Nigerian biofuel policy and incentives (2007) transform Nigeria into a biofuel economy? Energy Policy 54:352-359 
Ohimain EI (2013b) The challenges of liquid transportation fuels in Nigeria and the emergence of the Nigerian automotive biofuel programme. Res J Appl Sci Eng Technol 5(16):4058-4065

Ojeh VN (2012) Sustainable development and gas flaring activities: a case study of Ebedei area of Ukwuani LGA, Delta State, Nigeria. Resour Environ 2(4):169-174

Ojide M, Kareem S, Kari F, Gazi A, Matuin O (2012) Impact of gas industry on sustainable economy in Nigeria: further estimations through e-view. J Appl Sci 12:2244-2251

Okeke PN, Okpala CQ (2014) Effects of gas flaring on selected arable soil quality indicators in the Niger Delta, Nigeria. Sky J Soil Sci Environ Manag 3(1):001-005

Okonwu K, Mensah SI (2012) Effects of NPK (15:15:15) fertilizer on some growth indices of pumpkin. Asian J Agric Res 6:137-143

Okorie A (2018) The dominance of foreign capital and its impact on Indigenous technology development in the production of liquefied natural gas in Nigeria. Rev Afr Polit Econ 45:478-490

Olisemauche OO, Avwerosuoghene OP (2015) The effect of gas flaring on agricultural production of Okpai, Ndukwa East Local Government Area, Delta State, Nigeria. Stand Sci Res Essays 3 (9):266-272

Olobaniyi SB, Efe SI (2007) Comparative assessment of rainwater and groundwater in the oil producing area of Nigeria: environment and health implication. J Environ Health 6 (2):111-117

Olukoya OAP (2015) Negative effects of gas flaring on buildings and public health in oil producing communities: the Ogbia community, Bayelsa State case. Int J Environ Monit Prot 2(5):52-61

Orlando O (2006) Construction and networking of gas distribution infrastructure, Chartered Institute of Bankers of Nigeria, (2006) Oil and gas financing in Nigeria issues, challenges and prospects. The Chartered Institute of Bankers of Nigeria, Lagos, p 243

Osuji LC, Onojake CM (2004) Trace heavy metals associated with crude oil: a case study of Ebocha-8 oil-spill-polluted site in Niger Delta, Nigeria. Chem Biodivers 1(11):1708-1715

Otitoloju A, Dan-Patrick J (2010) Effects of gas flaring on blood parameters and respiratory system of laboratory mice, Mus musculus. Environmentalist 30:340-346

Ovuakporaye SI, Aloamaka CP, Ojieh AE, Ejebe DE, Mordi JC (2012) Effect of gas flaring on lung function among residents in gas flaring community in Delta State, Nigeria. Res J Environ Earth Sci 4(5):525-528

Oyedepo SO (2014) Towards achieving energy for sustainable development in Nigeria. Renew Sust Energ Rev 34:255-272

Ozabor F, Obisesan A (2015) Gas flaring: impacts on temperature, agriculture and the people of Ebedei in Delta State Nigeria. J Sustain Soc 4(2):5-12

Parry ML, Canziani OF, Palutikof JP, van der Linden PJ, Hanson CE (eds) (2007) Cross-chapter case study. In: Climate change 2007: impacts, adaptation and vulnerability. Contribution of working group II to the fourth assessment report of the Intergovernmental Panel on Climate Change. Cambridge University Press, Cambridge

Patz JA, Gibbs HK, Foley JA, Rogers JV, Smith KR (2007) Climate change and global health: quantifying a growing ethical crisis. EcoHealth 4:397-405

Pearce DW, Cline WR, Achanta AN, Fankhauser S, Pachauri RK, Tol RSJ et al (1996) The social costs of climate change: greenhouse damage and the benefits of control. In: Bruce JP, Lee H, Haites EF (eds) Climate change 1995: economic and social dimensions-contribution of working group III to the second assessment report of the Intergovernmental Panel on Climate Change. Cambridge University Press, Cambridge, pp 179-224

Rhodes CJ (2019) Sci Prog 102(1):73-89

Shaaban M, Petintin JO (2014) Renewable energy potentials in Nigeria: meeting rural energy needs. Renew Sustain Energy Rev 29:72-84

Silva RVD, Rodrigues LA, Maurício GSD, Marco AS, Bruna GD, Martins MA (2019) Biochar and mucuna increase papaya plant growth and nutrition, as well as soil fertility. Pesqui Agropecu Trop 49(e55210):1-10

Smith JL, Collins HP, Bailey VL (2010) The effect of young biochar on soil respiration. Soil Biol Biochem 42:2345-2347 
Sohi S, Lopez-Capel E, Krull E, Bol R (2009) Biochar, climate change and soil: a review to guide future research. CSIRO Land and Water science report, 5/09. CSIRO Land and Water, Canberra, $\mathrm{p} 02$

Sojinu OSS, Wang JZ, Sonibare OO, Zeng EY (2010) Polycyclic aromatic hydrocarbons in sediments and soils from oil exploration areas of the Niger Delta, Nigeria. J Hazard Mater 174(1-3):641-647

Sonibare J, Adebiyi F, Obanijesu E, Okelana O (2010) Air quality index pattern around petroleum production facilities. Manag Environ Qual Int J 21(3):379-392

Swanson J (2013) Climate-change mitigation potential of biochar: a review and framework for carbon accounting. MSc thesis, Duke Environmental Leadership Master of Environmental Management, Nicholas School of Environment, Duke University, Durham, pp 1-39

Tawari CC, Abowei JFN (2012) Air pollution in the Niger Delta area of Nigeria. Int J Fish Aquat Sci 1:94-117

Turkdogan MK, Fevzi K, Kazim K, Ilyas T, Ismail U (2003) Heavy metals in soil, vegetables and fruits in the endemic upper gastrointestinal cancer region of Turkey. Environ Toxicol Pharmacol 13:175-179

Ubani EC, Onyejekwe IM (2013) Environmental impact analyses of gas flaring in the Niger Delta region of Nigeria. Am J Sci Ind Res 4(2):246-252

Ujowundu CO, Nwaogu LA, Ujowundu FN, Belonwu DC (2013) Effect of gas flaring on the phytochemical and nutritional composition of Treculia africana and Vigna subterranean. Br Biotechnol J 3(3):293-304

Ukala E (2011) Gas flaring in Nigeria's Niger Delta: failed promises and reviving community voices. J Energy Clim Environ 97:97-126

UNFCCC (2015) Adoption of the Paris Agreement. https://unfccc.int/resource/docs/2015/cop21/ eng/109.pdf. Accessed 5 Nov 2019

Wang T, Camps-Arbestain M, Hedley M, Bishop P (2012) Predicting phosphorous bioavailability from high-ash biochars. Plant Soil 357:173-187

Weyant CL, Shepson PB, Subramanian R, Cambaliza MOL, Heimburger A, Mccabe D, Baum E, Stirm BH, Bond TC (2016) Black carbon emissions from associated natural gas flaring. Environ Sci Technol 500:2075-2081

Woolf D, Amonette JE, Street-Perrott FA, Lehmann J, Joseph S (2010) Sustainable biochar to mitigate global climate change. Nat Commun 1:56

Yaduma N, Kortelainen M, Wossink A (2013) Estimating mortality and economic costs of particulate air pollution in developing countries: the case of Nigeria. Environ Resour Econ 54:361-387

Zhao S, Alexandroff A (2019) Current and future struggles to eliminate coal. Energy Policy 129:511-520

Zhou Y, Cheng S, Chen D, Land J, Zhao B, Wei W (2014) A new statistical approach for establishing high-resolution emission inventory of primary gaseous air pollutants. Atmos Environ 94:392-401

Open Access This chapter is licensed under the terms of the Creative Commons Attribution 4.0 International License (http://creativecommons.org/licenses/by/4.0/), which permits use, sharing, adaptation, distribution and reproduction in any medium or format, as long as you give appropriate credit to the original author(s) and the source, provide a link to the Creative Commons license and indicate if changes were made.

The images or other third party material in this chapter are included in the chapter's Creative Commons license, unless indicated otherwise in a credit line to the material. If material is not included in the chapter's Creative Commons license and your intended use is not permitted by statutory regulation or exceeds the permitted use, you will need to obtain permission directly from the copyright holder. 